Nota científica

(Short communication)

\title{
FIRST REPORT OF THE GENUS UMBELLIGERUS DEITZ, 1975 (HEMIPTERA: MEMBRACIDAE: STEGASPIDINAE) FOR COLOMBIA
}

\section{Diana MARCEla TORRES DOMÍNGUEZ ${ }^{1 *}$, CARMen Elisa POSSO GÓMEZ ${ }^{1}$, LaUra Catalina GONZÁLEZ MOZO², RANULFO GONZÁLEZ OBANDO ${ }^{1}$}

\author{
${ }^{1}$ Universidad del Valle, Facultad de Ciencias Naturales y Exactas, Grupo de Investigaciones Entomológicas. A.A. 25360. Cali, \\ Valle del Cauca, Colombia.<dianamarcela24@gmail.com>; <carmen.posso@correounivalle.edu.co>; \\ <ranulfo.gonzalez@correounivalle.edu.co> \\ ${ }^{2}$ Universidad Nacional de Colombia, Facultad de Ciencias Agrarias, Grupo de Investigación Sistemática de Insectos Agronomía \\ (SIA), Museo Entomológico UNAB. A.A. 14490. Bogotá, Cundinamarca, Colombia. <lacgonzalezmo@unal.edu.co> \\ *Autor de correspondencia: <dianamarcela24@gmail.com> \\ Recibido: 05/06/2017; aceptado: 18/06/2018; publicado en línea: 29/03/2019 \\ Editor responsable: Pedro Reyes-Castillo†; Magdalena Cruz Rosales
}

Torres-Domínguez, D. M., Posso-Gómez, C. E., González-Mozo, L. C., González-Obando, R. (2019) First report of the genus Umbelligerus Deitz, 1975 (Hemiptera: Membracidae: Stegaspidinae) for Colombia. Acta Zoológica Mexicana (nueva serie), 35, 1-4. https://doi.org/10.21829/azm.2019.3502195

\begin{abstract}
The genus Umbelligerus is reported for the first time in Colombia from the review of a male specimen found in the department of Amazonas. This specimen was deposited in the Museo de Entomología de la Universidad del Valle. A map of the known geographical distribution and photographs of the Umbelligerus peruviensis are included.
\end{abstract}

Torres-Domínguez, D. M., Posso-Gómez, C. E., González-Mozo, L. C., González-Obando, R. (2019) Primer reporte del género Umbelligerus Deitz, 1975 (Hemiptera: Membracidae: Stegaspidinae) para Colombia. Acta Zoológica Mexicana (nueva serie), 35, 1-4. https://doi.org/10.21829/azm.2019.3502195

RESUMEN. El género Umbelligerus se reporta por primera vez para Colombia a partir de la revisión de un espécimen macho proveniente del departamento de Amazonas. El ejemplar fue depositado en el Museo de Entomología de la Universidad del Valle. Se proporciona material fotográfico del espécimen revisado y un mapa de la distribución conocida para Umbelligerus peruviensis.

Membracidae comprises about 400 genera and over 3,200 species (McKamey, 1998; Dietrich et al., 2001; Flórez et al., 2015) grouped into nine subfamilies, eight of which are restricted to the New World (Deitz et al., 2008; Campodonico, 2015). The distribution of this family is cosmopolitan, in the Neotropical region are reported 216 genera and approximately 1,600 species (Wood, 1993; McKamey, 1998; Dietrich et al., 2001; Flórez et al., 2015).

The genus Umbelligerus was described by Deitz in 1975 to include ornamented species of treehoppers with an antler-like pronotum. It is characterized by the stalked ocelli and compound eyes, 
pronotum with umbelliform process dorsally, not concealing the scutellum or the forewings in repose; the forewing and hindwing with one $\mathrm{r}-\mathrm{m}$ and one $\mathrm{m}$-cu crossvein; tibiae not foliaceous; metatibiae with cucullate setae in row II, first tarsomere has one cucullate setae apically and the abdomen without conspicuous punctuation (Deitz, 1975; Flynn, 2014). The genus has nowadyas five described species: Umbelligerus peruviensis Deitz, 1975, Umbelligerus furcillatus Sakakibara, 1981, Umbelligerus woldai Sakakibara, 1981, Umbelligerus convergens Flynn, 2014 and Umbelligerus stockwelli Flynn, 2014 distributed in Central and South America (Cryan \& Deitz, 2000; Flynn, 2014). Umbelligerus peruviensis is known from Brazil, Peru and Venezuela (Fig. 1), whereas $U$. furcillatus is restricted only to Brazil, U. woldai in Costa Rica and Panama, U. convergens is only in Panama, and U. stockwelli know from Panama and Costa Rica.

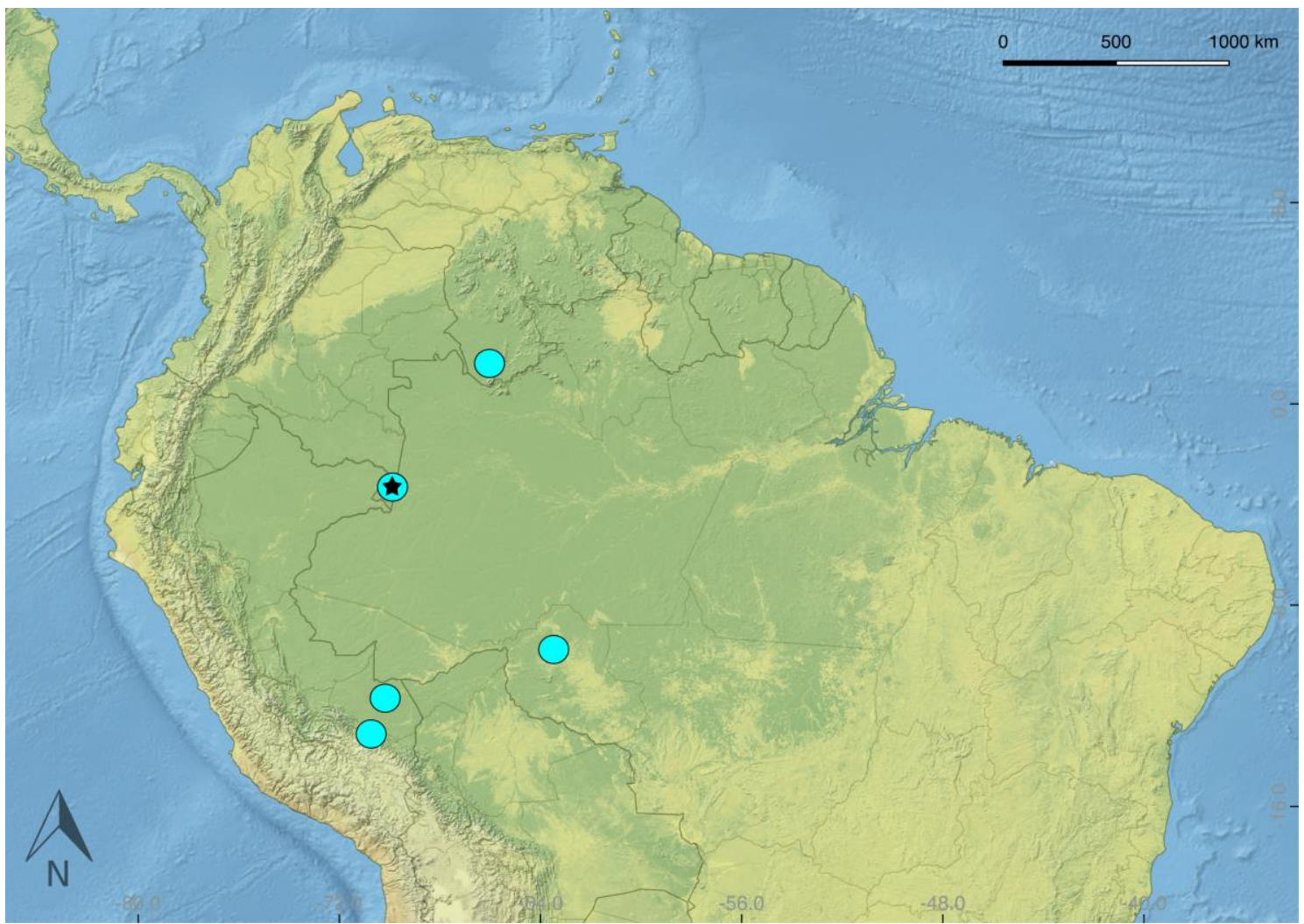

Figure 1. Know geographical distribution for Umbelligerus peruviensis Deitz, 1975 including the new record from the Department of Amazonas in Colombia (blue dot with star black on the map). Records according with Flynn 2014.

Umbelligerus peruviensis is the type species of the genus and its features are, the head with elevated vertex and bearing ocelli on dark elevated nodules, compound eyes dark (Figs. 2-4); pronotum with white longitudinal band laterally on each side (Fig. 2, 4), with black umbelliform process dorsally; elevated central stalk and simple branch; distally presents two anterolateral branches each of which has three secondary branches (Fig. 2); scutellum exposed with white areas laterally ranging to the back; legs slightly darker distally (Fig. 2-4) and abdomen with black apex dorsally. According with Flynn (2014) U. peruviensis is most closely related to $U$. furcillatus but $U$. peruviensis has a small prong present in each of the posterior branches of the pronotal extension (Fig. 2). The specimens of U. peruviensis of the type series (1 9 and $2 \AA$ ) and the reviewed by Flynn (2014) (2ᄋ and 3 ${ }^{3}$ ) was collected in the years 1952, 1984, 1992, 1993 and 1999, in the rainforest by blacklight traps and mercury vapor lamp at altitudes of 140, 240 and $900 \mathrm{~m}$. 

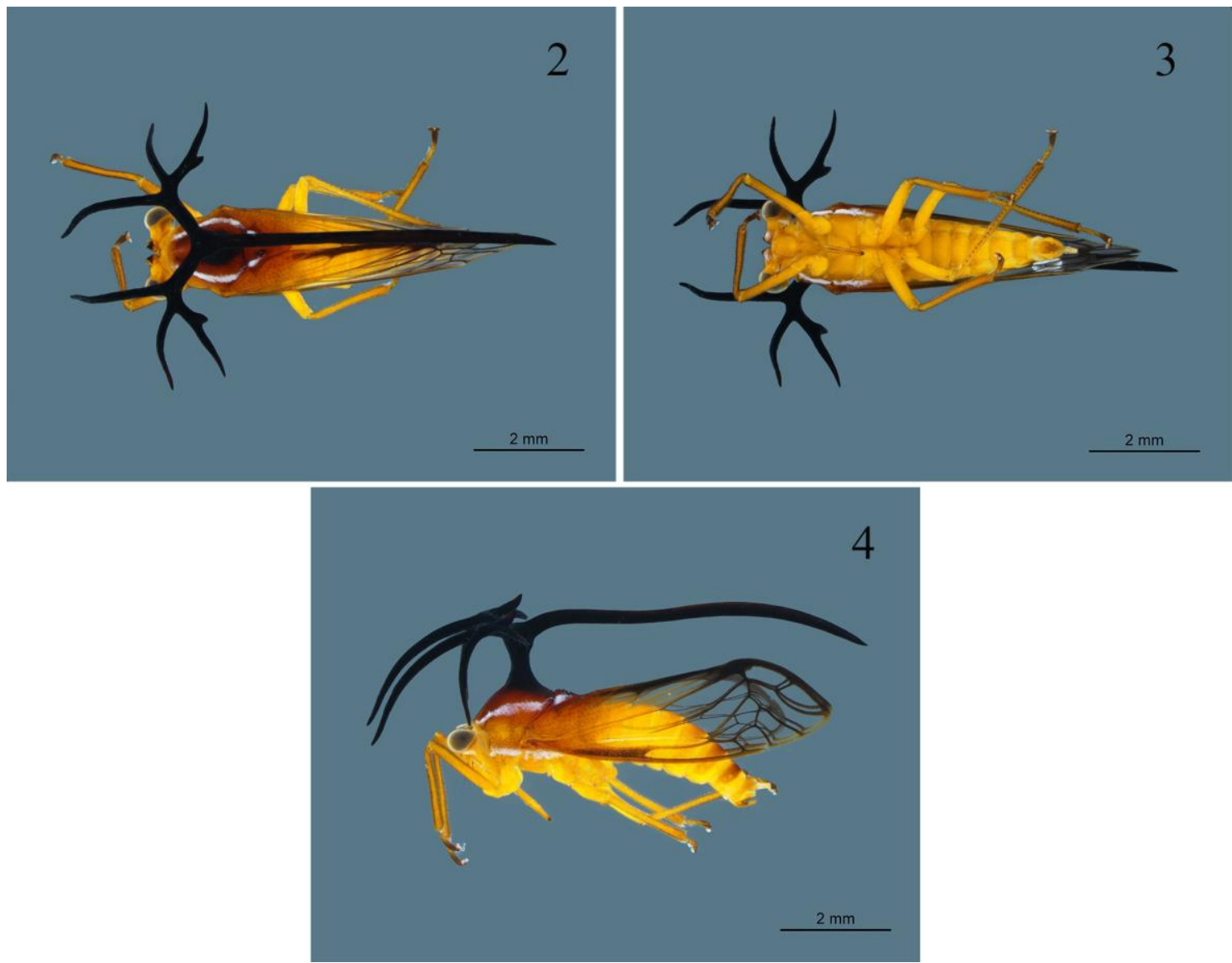

Figure 2-4. Umbelligerus peruviensis Deitz, 1975. 2) dorsal view; 3) ventral view; 4) lateral view. Photo by Juan Felipe Ortega and Diana Torres.

One male specimen deposited at the Museo de Entomología de la Universidad del Valle, Santiago de Cali, Colombia (MUSENUV: 27748) was examined. It is from Amazonas Leticia, San Martín de Amacayacu. $3^{\circ} 42^{\prime} 19^{\prime}$ 'S $, 70^{\circ} 20^{\prime} 26,1^{\prime \prime} W$, altitude 70 m. 12-13.VIII.2015. White led light trap located in the forest canopy (10 m high); collectors: R. González, N. Calderón, O. Saenz and N. Carrejo. The determination of the specimen was carried out using the Flynn (2014) key and the revision of original description of Dietz (1975). The photos were taken using a Nikon SMZ 1500 stereo microscope, a Nikon DS-Ril U3 camera and finally were edited with NIS-Elements software.

This finding is the first report of the genus and species for Colombia. It is noteworthy that the specimen was collected in the lowest altitude known for species $(70 \mathrm{~m})$ and using white led light traps in more than 10 meters above the ground, providing an interesting fact about the habitat of these insects.

ACKNOWLEDGEMENTS. We thank the collectors Nancy Carrejo, Oscar Saenz, Nadia Calderón and the Museo de Entomología de la Universidad del Valle (MUSENUV) for allowing us the review of the material. Thanks also to Juan Felipe Ortega and Laboratorio de imágenes del Posgrado en Ciencias-Biología at the Universidad del Valle for assistance with photographs; to Camilo Flórez by bibliographical support and Bryan Ospina Jara by the English review of the document. Special thanks to The Tikuna community of San Martín de Amacayacu for field support and the project funded by Colciencias (Code 1106-659-44236) Revisión Taxonómica y Endemismos de los Psócidos (Psocodea: 'Psocoptera') de Parques Naturales de Colombia. 


\section{LITERATURE CITED}

Campodonico, J. F. (2015) On the presence of Ilithucia nasuta (Stål, 1859) (Hemiptera: Membracidae) in the north of Chile. Biodiversity and Natural History, 1, 9-11.

http://www.biodiversnathist.com/index.php/bnh/article/view/5/7

Cryan, J. R., Deitz, L. L. (2000) Review of the New World Treehopper Tribe Stegaspidini (Hemiptera: Membracidae: Stegaspidinae): III: Flexocentrus Goding, Stylocentrus Stål, and Umbelligerus Deitz. Proceeding of the Entomological Society of Washington, 102 (1), 82-98.

Deitz, L. L. (1975) Classification of the higher categories of the New World treehoppers (Homoptera: Membracidae). North Carolina Agricultural Experiment Station Technical Bulletin, 225 (1-4), 1177.

Deitz, L. L., Wallace, M. S., Dietrich, C. H., McKamey, S. H., Rothschild, M. J. (2008) Treehoppers Dr. Metcalf: A resource on cicadas, leafhoppers, planthoppers, spittlebugs, and treehoppers. Available at: http://www.lib.ncsu.edu/specialcollections/digital/metcalf/treehoppers.html (accesed on september 2015).

Dietrich, C. H., McKamey, S. H., Deitz, L. L. (2001) Morphology-based phylogeny of the treehopper family Membracidae (Hemiptera: Cicadomorpha: Membracoidea). Systematic Entomology, 26, 213-239. http://dx.doi.org/10.1046/j.1365-3113.2001.00140.x

Flórez-V, C., Wolff E. M. I., Cardona-Duque, J. (2015) Contribution to the taxonomy of the family Membracidae Rafinesque (Hemiptera: Auchenorrhyncha) in Colombia. Zootaxa, 3910 (1), 1-261. http://dx.doi.org/10.11646/zootaxa.3910.1.1

Flynn, D. J. (2014) Review of the Genus Umbelligerus Deitz with Description of Two New Species from Panama and Key to Adults (Hemiptera: Membracidae). Proceedings of the Entomological Society of Washington, 116 (2), 145-154.

http://dx.doi.org/10.4289/0013-8797.116.2.145

McKamey, S. H. (1998) Taxonomic catalogue of the Membracoidea (exclusive of leafhoppers): second supplement to fascicle 1- Membracidae of the general catalogue of the Hemiptera. Memoirs of the American Entomological Institute, 60, 1-377.

Wood, T. K. (1993) Diversity in the New World Membracidae. Annual Review of Entomology, 38, 409433.

http://dx.doi.org/10.1146/annurev.en.38.010193.002205 